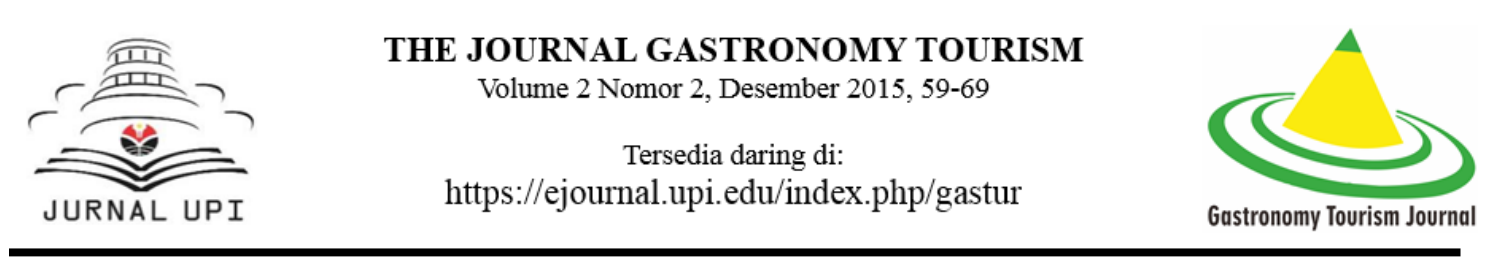

\title{
ANALISIS KETIDAKPUASAN KONSUMEN TERHADAP MENU KATEGORI DOG DI RESTORAN SANGKURIANG BANDUNG
}

\author{
Alia Zulfah Fahriyyah, Ratih Hurriyati, Wendi Andriatna \\ Program Studi Manajemen Industri Katering \\ Fakultas Pendidikan Ilmu Pengetahuan Sosial \\ Universitas Pendidikan Indonesia
}

\begin{abstract}
ABSTRAK
Penelitian ini bertujuan untuk menganalisis faktor-faktor yang berpengaruh terhadap ketidakpuasan konsumen terhadap menu tidan populer dan tidak menguntunhkan secara simultan dan parsial. Pada penelitian ini terdapa tiga variabel bebas yaitu kualitas produk, kualitas pelayanan dan harga serta variabel tidak bebas kepuasan konsumen dengan metode deskriptif dan diolah dengan menggunakan program spss 20 dengan kuisioner sebagai alat pengumpul dan pengolahan data. Populasi pada pebelitian ini ialah 50330 konsumen pada tahun 2014 di Restoran Sangkuriang Bandunng dan diambil sampel sebanyak 100 konsumen. Untuk teknik pengumpulan data dilakukan dnegan cara observasi, wawanara dan penyebaran kuisioner. Berdasarkan hasil penelitian diperoleh hasil bahwa kualitas produk dah harga memiliki pengaruh positif tidak signifikan sedangkan kualitas pelayanan memiliki pengaruh positif signifikan. Hal ini dapat disebabkan oleh penetapan standar resp dan standar porsi yang belum sesuai.
\end{abstract}

Kata kunci : Ketidakpuasan Konsumen, Menu Tidak Populer dan Tidak Menguntungkan dan Restoran Sangkuriang.

\section{PENDAHULUAN}

Pariwisata, bila dilihat sebagai sesuatu jenis usaha yang memiliki nilai ekonomi, maka pariwisata adalah sebagai suatu proses yang dapat menciptakan nilai tambah terhadap barang dan atau jasa sebagai satu kesatuan produk, baik yang nampak atau nyata (tangible product) dan yang tidak tampak atau tidak nyata (intangible product), Sulastiyono (2008, hlm.3).

Sektor pariwisata sebagai kegiatan perekonomian telah menjadi andalan dan prioritas pengembangan bagi sejumlah negara, terlebih bagi negara berkembang seperti Indonesia yang memiliki potensi wilayah yang luas dengan daya tarik wisata yang cukup besar. Pariwisata di Indonesia merupakan salah satu penunjang perekonomian yang memiliki prospek yang cerah. (Zain dan Taufik, 2010, hlm.1). Berdasarkan laporan The World Travel \& Tourism Council (WTTC), Indonesia merupakan negara dengan pertumbuhan pariwisata paling bagus diantara negaranegara anggota G20.

Sejak dibukanya jalan Tol Cipularang, kota bandung menjadi tujuan utama dalam menikamti liburan akhir pekan terutama daro masyarakat yang berasal dari Jakarta dan sekitarnya. Selain menjadi kota wisata belanja, kota Bandung juga dikenal dengan sejumlah besar bangunan lama berasitektur peninggalan Belanda, diantaranya Gedung Sate, Gedung pakuan, Gedung Dwi Warna, Villa Isola dan lain-lain selain itu Bandung juga memliki tujuan wisata lainnya (Osndikbud, 2013). Pada saat ini Bandung selain terkenal dengan daerah wisata belanja, juga 
terkenal sebagai pusat kuliner lokal Jawa Barat yaitu aneka macam kuliner sunda maupun kuliner nusantara tersedia di Kota Bandung, hal tersebut menjadi daya tarik bagi wisatawan untuk menjadikan kota Bandung sebagai tujuan wisata (Oda, 2007)

Restoran merupakan suatu tempat dimana seseorang yang akan menjadi tamu yang akan mendapatkan pelayanan untuk menikmati makanan baik di pagi hari, siang hari maupun malam hari sesuai dengan jam buka dan oleh tamu yang menikmati hidangan itu harus membayar sesuai dengan harga yang ditentukan sesuai daftar yang disediakan di restoran itu. Setiap restoran akan memiliki produk yang ditawarkan kepada tamu, produk tersebut terdapat pada sebuah daftar yang disebut dengan menu. Pada umumnya menu sendiri memiliki tiga macam arti yaitu sebagai daftar makanan yang disertai dengan harga, sebagai makanan yang disajikan dan sebagai hidangan yang disajikan pada waktu tertentu.

Restoran Sangkuriang merupakan restoran yang nyaman untuk dikunjungi bagi keluarga maupun kalangan perkantoran. Restoran Sangkuriang memiliki kapasitas untuk 120 orang dengan dekorasi restoran yang didominasi oleh budaya sunda. Di restoran ini juga terdapat fasilitas saung untuk pengunjung yang datang sebagai grup maupun keluarga. Restoran Sangkuriang memiliki banyak pilihan menu, yang didominasi oleh makanan khas sunda.

Dari sekian banyak menu yang dimiliki oleh restoran tentu tidak semua menu menghasilkan keuntungan bagi restoran. Untuk mengetahui hal tersebut restoran dapat melakukan evaluasi menu dengan menggunakan analisis yang disebut menu engineering. Menurut Ninemeier dan Hayes (2006, hlm.202) menu engineering merupakan metode untuk mengevaluasi menu dengan tujuan meningkatkan penjualan produk yang paling populer dan menguntungkan. Dari analisis menu engineering ini akan didapat hasil empat klasifikasi menu yaitu :

1. Star, menu yang tergolong ke dalam kategori star berarti menu tersebut menguntungkan dan populer.

2. Plow Hore, menu yang tergolong ke dalam kategori ini berarti menu ini populer namun tidak menguntungkan.

3. Puzzle, menu yang tergolong kedalam menu ini berarti menu ini menguntungkan namun tidak populer.

4. Dog, menu yang tergolong ke dalam kategori ini berarti menu yang tidak populer dan tidak menguntungkan.

Berdasarkan observasi yang dilakukan, penulis mendapatkan beberapa data yaitu sales history, food cost dan selling price setelah itu data diolah dengan melakukan analisis menu engineering dan diperoleh hasil yaitu sebagai berikut:

Daftar Menu Kategori Dog (Tidak Populer dan Tidak menguntungkan)
Restoran Sangkuriang Periode Januari - Juni 2015
\begin{tabular}{|c|c|}
\hline No & Menu \\
\hline 1 & Telur Mata Sapi \\
\hline 2 & Sambel Goang \\
\hline 3 & Pencok Kacang/leunca \\
\hline 4 & Gurame Goreng Pedas \\
\hline
\end{tabular}




\begin{tabular}{|c|c|}
\hline 5 & Gurame Acar Kuning \\
\hline 6 & Asin Gabus \\
\hline 7 & Nila Asam Manis \\
\hline 8 & Sup Kosong \\
\hline 9 & Nasi putih Timbel \\
\hline 10 & Nila Renyah Pedas \\
\hline 11 & Telur Rebus \\
\hline
\end{tabular}

\section{Sumber : data hasil olahan penulis 2015}

Berdasarkan tabel 1.3 dapat diketahui bahwa Restoran Sangkuriang memiliki 10 menu yang tergolong kedalam kategori dog yaitu menu yang tidak populer dan tidak menguntungkan. Adapun beberapa faktor yang memepengaruhi klasifikasi menu menjadi tidak populer dan tidak menguntungkan daripada menu lainnya, diantaranya ialah:

a. Kulaits produk

Kulitas produk di Restoran sangkuriang dapat dilihat dari penampilan menu, rasa/kelezatan menu, porsi menu, kebersihan menu dan waktu pembuatan menu.

b. Kulitas pelayanan

Kulitas pelayanan di Restoran Sangkuriang dapat dilihat dari ketepatan dan kecepatan pelyanan, kemampuan karyawan menangani tamu, perilaku atau keramahan karyawan, empati karyawan dan penampilan karyawan.

c. Harga

Harga di Restoran Sangkuriang dapat dilihat dari kesesuaian harga dengan menu dan keterjangkauan harga menu oleh konsumen.

Dari ketiga faktor diatas dapat dijadikan indikator untuk mengetahui kepuasan atau ketidakpuasan konsumen terhadap menu di Restoran Sangkuriang. Berdasarkan paparan diatas penulis akan membuat karya ilmiah ini dengan judul "ANALISIS KETIDAKPUASAN KONSUMEN TERHADAP MENU KATEGORI DOG DI RESTORAN SANGKURIANG".

\section{METODE PENELITIAN}

Objek dalam penelitian ini ialah Restoran Sangkuriang Bandung. berkenaan dengan subjek penelitian, dalam penelitian ini aspek yang diteliti ialah ketidak puasan konsumen terhadap menu kategori dog dengan variabel nya ialah kualitas produk, kualitas pelayanan dan harga.

Penelitian ini menggunakan metode deskriptif verifikatif.

menurut Wiratha (2006, hlm.154) penelitian deskriptif berkaitan dengan pengumpulan data untuk memberikan gambaran atau penegasan suatu konsep atau gejala, juga menjawab pertanyaan pertanyaan sehubungan dengan status subjek penelitian. Penelitian deskriptif bertujuan menggambarkan secara sistematik dan akurat fakta dan karakteristik populasi atau bidang tertentu. Menurut Travens Travens dalam Husein Umar (2001, hlm.21) penelitian deskriptif merupakan penelitian yang dilakukan untuk mengetahui nilai variabel mandiri. Baik 
(independen) tanpa membuat perbandingan akan menghubungkan dengan variabel lain. Melalui jenis penelitian deskriptif ini maka dapat diperoleh mengenai deskripsi pengaruh kualitas produk, kualitas pelayanan dan harga terhadap ketidakpuasan konsumen pelanggan di Restoran Sangkuriang. Sedangkan penelitian verifikatif menguji kebenaran hipotesis yang dilakukan melalui pengumpulan data di lapangan, dalam hal ini penelitian verifikatif bertujuan untuk mengetahui pengaruh kualitas produk, kualitas pelayanan dan harga terhadap ketidakpuasan pelanggan di Restoran Sangkuriang.

Hasil penelitian yang valid bila kesamaan antara data yang terkumpul dengan data yang sesungguhmya terjadi pada obyek yang diteliti. Untuk mencari nilai validitas disebuah item, kita mengkorelasikan skor item dengan total itemitem tersebut. Jika koefisien korelasinya sama atau diatas 0.3 maka item tersebut dinyatakan valid, tetapi bila nilai korelasinya dibawah 0.3 maka item tersebut dinyatakan tidak valid, menurut Sugiyono (2010, hlm 348). Menurut arikunto (2009, hlm 44) hasil suatu ukuran yang menunjukan tingkat-tingkat kevalidan suatu instrumen. Suatu onstrumen yang valid mempunyai validitas yang tinggi. Sebaliknya instrumen yang kurang valid berarti memiliki validitas yang rendah.

Hasil Pengujian Validitas

\begin{tabular}{|c|c|c|c|c|}
\hline No & Variabel & $\begin{array}{c}\text { r } \\
\text { hitung }\end{array}$ & r tabel & Ket \\
\hline \multicolumn{5}{|c|}{ Kualitas Product (X1) } \\
\hline 1 & P1 & 0.849 & 0.487 & VALID \\
\hline 2 & P2 & 0.821 & 0.487 & VALID \\
\hline 3 & P3 & 0.752 & 0.487 & VALID \\
\hline 4 & P4 & 0.754 & 0.487 & VALID \\
\hline 5 & P5 & 0.818 & 0.487 & VALID \\
\hline \multicolumn{5}{|c|}{ Kualitas Product (X2) } \\
\hline 6 & P6 & 0.853 & 0.487 & VALID \\
\hline 7 & P7 & 0.808 & 0.487 & VALID \\
\hline 8 & P8 & 0.786 & 0.487 & VALID \\
\hline 9 & P9 & 0.826 & 0.487 & VALID \\
\hline 10 & P10 & 0.703 & 0.487 & VALID \\
\hline \multicolumn{5}{|c|}{ Harga (X3) } \\
\hline 11 & P11 & 0.863 & 0.487 & VALID \\
\hline 12 & P12 & 0.848 & 0.487 & VALID \\
\hline \multicolumn{5}{|c|}{ Kepuasan Konsumen (Y) } \\
\hline 13 & P13 & 0.722 & 0.487 & VALID \\
\hline 14 & P14 & 0.878 & 0.487 & VALID \\
\hline 15 & P15 & 0.839 & 0.487 & VALID \\
\hline
\end{tabular}

Sumber : Pengolahan Data Penelitian 2015

Menurut Arikunto (2006, hlm 154) menyatakan reliabilitas menunjuk pada suatu pengertian bahwa sesuatu instrumen cukup dapat dipercaya untuk digunakan sebagai alat pengumpul data karena instrumen tersebut sudah baik. 
Uji reliabilitas digunakan untuk mengukur sejauh mana hasil pengukuran tetap konsisten bila dilakukan pengukuran dua kali dengan alat ukur (kuisioner) yang sama. Untuk menguji reliabilitas digunakan dengan cara mencobakan instrumennya beberapa kali pada responden. Jadi dalam hal ini instrumen dan respondennya sama tetapi waktunya yang berbeda. Reliabilitas diukur koefisien korelasi antara percobaan pertama dengan yang berikutnya. Bila koefisien korelasi positif dan signifikan maka instrumen tersebut sudah dinyatakan reliabel.

\section{Hasil Pengujian Reliabilitas}

\begin{tabular}{|l|c|c|}
\hline Variabel & $\begin{array}{c}\text { Koefisien } \\
\text { Reliabilit } \\
\text { as }\end{array}$ & Keterangan \\
\hline $\begin{array}{l}\text { Kualitas } \\
\text { Produk }\end{array}$ & 0.845 & Reliabel \\
\hline $\begin{array}{l}\text { Kualitas } \\
\text { Pelayanan }\end{array}$ & 0.849 & Reliabel \\
\hline Harga & 0.633 & Reliabel \\
\hline $\begin{array}{l}\text { Kepuasan } \\
\text { Konsumen }\end{array}$ & 0.748 & Reliabel \\
\hline
\end{tabular}

Sumber : pengolahan data penelitan 2015

\section{HASIL PENEILITIAN}

Berdasarkan pengolahan data dari kuisioner yang telah disebar, didapat karakteristik responden di Restoran Sangkuriang ialah :

1. $57 \%$ perempuan

2. $51 \%$ usia $30-40$ tahun

3. $36 \%$ berprofesi sebagai Pegawai negeri

4. $46 \%$ berdomisili di luar Bandung.

Dari kuisioner yang telah disebar menghasilkan garis kontinum dari kualitas produk yang berada di kelas cukup puas dengan nilai 1598 diantara 1300 - 1700, lalu garis kontinum dari variabel kualitas pelayanan berada di kelas cukup puas dengan nialai 1618 diantara nilai 1300 dan 1700 dan variabel harga juga berada dikelas cukup puas dengan nilai 590 diantara $520-680$.

Analisis ini digunakan untuk mengetahui derajat atau hubungan antara variabel kualitas produk $\left(\mathrm{X}_{1}\right)$, kualitas pelayanan $\left(\mathrm{X}_{2}\right)$ dan harga $\left(\mathrm{X}_{3}\right)$ terhadap ketidakpuasan konsumen di Restoran Sangkuriang Bandung.

\section{Tabel Koefisien Korelasi dan Koefisien}

\section{Determinasi}

\begin{tabular}{l|r|r|r|r|}
\hline Model & $\mathrm{R}$ & $\mathrm{R}$ Square & $\begin{array}{c}\text { Adjusted R } \\
\text { Square }\end{array}$ & $\begin{array}{c}\text { Std. Error of } \\
\text { the Estimate }\end{array}$ \\
\hline 1 &, $607^{\mathrm{a}}$ &, 369 &, 349 & 1,707 \\
\hline
\end{tabular}
a. Predictors: (Constant), X3, X1, X2
Sumber : Pengolahan Data Penelitian: 2015

Berdasarkan tabel 4.25 diatas maka dapat diketahui bahwa koefisien antara kualitas produk, kualitas pelayanan dan harga terhadap ketidakouasan konsumen di Restoran Sangkuriang Bandung sebesar 0.607. korelasi yang terjadi adalah 
korelasi kuat positif, yaitu diantara 0.600-0.799, seperti yang terlihat pada tabel dibawah ini :

Tabel Interpretasi Koefisien Korelasi

\begin{tabular}{|c|c|}
\hline Interval Koefisien & Tingkat Hubungan \\
\hline $0,00-0,199$ & Sangat Rendah \\
\hline $0,20-0,399$ & Rendah \\
\hline $0,40-0,599$ & Cukup \\
\hline $0,60-0,799$ & Kuat \\
\hline $0,80-1,000$ & Sangat Kuat \\
\hline
\end{tabular}

Sumber : Riduwan (2010, hlm 228)

Analisis regresi digunakan untuk mengetahui seberapa kuat dan seberapa besar nilai pengaruh antara kualitas produk, kualitas pelayanan dan harga terhadap ketidakpuasan konsumen, berikut adalah tabel untuk melihat signifikan atau tidaknya pengaruh masing-masing variabel independent terhadap variabel dependent berdasarkan IBM SPSS Statistics 22.0

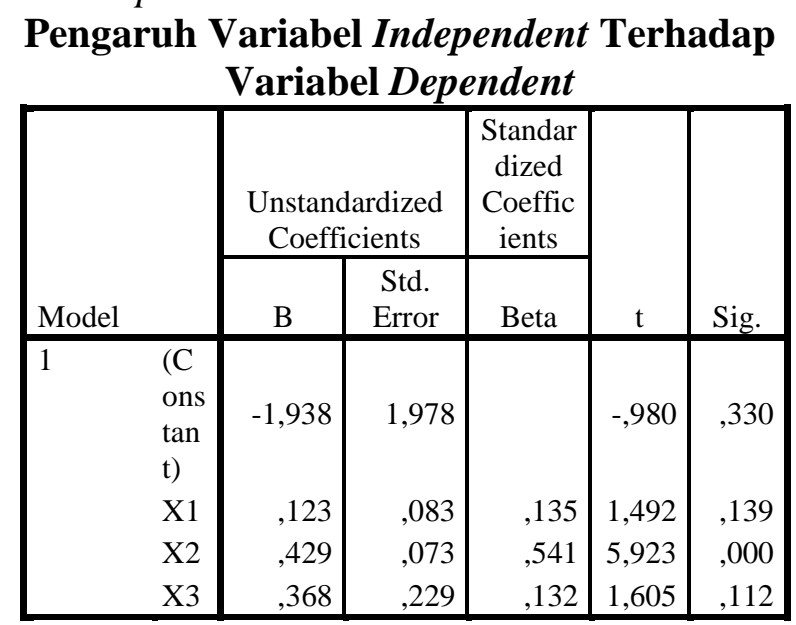

a. Dependent Variable: $\mathrm{Y}$

Sumber : Pengolahan Data Penelitian: 2015

Berdasarkan tabel 4.27 dapat diketahui besarnya pengaruh kualitas produk $\left(\mathrm{X}_{1}\right)$, kualitas pelayanan $\left(\mathrm{X}_{2}\right)$ dan harga $\left(\mathrm{X}_{3}\right)$ terhadap ketidakpuasan konsumen di Restoran Sangkuriang Bandung. berikut adalah penjelasannya :

1. Kualitas produk $\left(\mathrm{X}_{1}\right)$ berpengaruh terhadap ketidakpuasan konsumen $(\mathrm{Y}) \mathrm{di}$ Restoran Sangkuriang Bandung sebesar 1.492 karena $t_{\text {hitung positif maka }}$ pengaruh yang terjadi adalah positif atau dapat diartikan semakin tinggi atau baik kualitas produk maka semakin meningkat juga kepuasan konsumen.

2. Kualitas pelayanan $\left(\mathrm{X}_{2}\right)$ berpengaruh terhadap ketidakpuasan konsumen (Y) di Restoran Sangkuriang Bandung sebesar 5.923 karena $t_{\text {hitung }}$ positif maka pengaruh yang terjadi adalah positif atau dapat diartikan semakin tinggi atau baik kualitas pelayanan maka semakin meningkat kepuasan konsumen yang artinya mengurangi ketidakpuasan konsumen.

3. Harga ( $\left.\mathrm{X}_{3}\right)$ berpengaruh terhadap ketidakpuasan konsumen (Y) di Restoran Sangkuriang Bandung sebesar 1.605 karena $t_{\text {hitung positif maka pengaruh }}$ yang terjadi adalah positif atau dapat diartikan bahwa semakin tinggi atau baik 
kesesuaian haga maka semakin meningkat juga kepuasan konsumen dan berkurangnya ketidakpuasan konsumen.

Berdasarkan tabel diatas, diperoleh persamaan regresi sebagai berikut :

$$
\mathrm{Y}=-1.938+0.123 \mathrm{X}_{1}+0.429 \mathrm{X}_{2}+0.368 \mathrm{X}_{3}
$$

Dimana :

$\mathrm{Y}=$ Ketidakpuasan Konsumen

$\mathrm{X}_{1}=$ Kualitas Produk

$\mathrm{X}_{2}=$ Kualitas Pelayanan

$\mathrm{X}_{3}=$ Harga

Dari persmaan tersebutdapat dijelaskan sebagai berikut :

1. Jika diasumsikan variabel bebas (kualitas produk, kulaitas pelayanan dan harga) diajukan tetap, maka nilai dari kepuasan konsumen di Restoran Sangkuriang Bandung sebesar 1.938.

2. Jika tingkat kesesuaian kualitas produk naik sebsesar satu satuan maka kepuasan konsumen mengalami kenaikan sebesar 0.123 satuan dan sebaliknya apabila terjadi penurunan pada tingkat kesesuaian kualitas produk sebesar satu satuan maka kepuasan monsumen akan menurun sebesar 0.123 dengan asumsi bahwa kualitas pelayanan tetap, hali ini menunjukan semakin tinggi tingkat kualitas produk maka semakin menurun ketidakpuasan konsumen di Restoran Sangkuriang.

3. Jika tingkat kesesuaian kualitas pelayanan naik sebsesar satu satuan maka kepuasan konsumen mengalami kenaikan sebesar 0.429 satuan dan sebaliknya apabila terjadi penurunan pada tingkat kesesuaian kualitas pelayanan sebesar satu satuan maka kepuasan monsumen akan menurun sebesar 0.429 dengan asumsi bahwa kualitas pelayanan tetap, hali ini menunjukan semakin tinggi tingkat kualitas pelayanan maka semakin menurun ketidakpuasan konsumen di Restoran Sangkuriang.

4. Jika tingkat kesesuaian harga naik sebsesar satu satuan maka kepuasan konsumen mengalami kenaikan sebesar 0.368 satuan dan sebaliknya apabila terjadi penurunan pada tingkat kesesuaian harga sebesar satu satuan maka kepuasan monsumen akan menurun sebesar 0.368 dengan asumsi bahwa kesesuaian harga tetap, hal ini menunjukan semakin tinggi tingkat kesesuaian harga maka semakin menurun ketidakpuasan konsumen di Restoran Sangkuriang.

Uji signifikan dilakukan dengannbantuan IBM SPSS Statistics 22.0. hasil uji F dapat dilihat pada tabel 4.26 dibawah ini :

Tabel 4.28 menunjukan nilai $\mathrm{F}_{\text {hitung }}=18.677$ dengan nilai signifikansi

0.000 sedangkan $\mathrm{F}_{\text {tabel }}=2.14$ karena nilai $\mathrm{F}_{\text {hitung }}>\mathrm{F}_{\text {tabel }}$ dan signifikansi lebih kecil dari taraf signifikan $10 \%$ artinya variabel kesesuaian kualitas produk, kualitas pelayanan dan harga bersama-sama mempengaruhi ketidakpuasan konsumen secara signifikan.

Nilai $t_{h i t u n g}$ yang terdapat pada tabel 4.26 digunakan untuk mengukur tingkat signifikansi pengaruh variabel $\mathrm{X}_{1}, \mathrm{X}_{2}$ dan $\mathrm{X}_{3}$ terhadap $\mathrm{Y}$ dengan $\mathrm{dk}$ (derajat kebebasab) $=\mathrm{N}-\mathrm{k}$, dimana $\mathrm{N}=$ jumlah sampel dan $\mathrm{k}=$ jumlah variabel $(\mathrm{k}=4)$ sehingga $\mathrm{db}=100-4$, maka nilai $t_{\text {hitung }}$ dengan $\mathrm{dk}=96$ dan taraf kepercayaan $90 \%$ hasil $t_{\text {tabel }}$ nya adalah 1.661 . 
Berdasarkan tabel 4.25 diperoleh nilai $t_{\text {hitung }}$ untuk masing-masing variabel bebas sebagai berikut :

Tabel Hasil Pengujian Hipotesis

\begin{tabular}{|c|c|c|c|}
\hline Variabel & $\begin{array}{c}\text { T } \\
\text { hitung }\end{array}$ & $\begin{array}{c}\text { T } \\
\text { tabel }\end{array}$ & Makna \\
\hline $\begin{array}{c}\text { Kualitas } \\
\text { Produk }\end{array}$ & 1.492 & 1.661 & Signifikan \\
\hline $\begin{array}{c}\text { Kualitas } \\
\text { Pelayanan }\end{array}$ & 5.923 & 1.661 & Signifikan \\
\hline Harga & 1.605 & 1.661 & Signifikan \\
\hline
\end{tabular}

Sumber : Pengolahan Data Penelitian: 2015

Pada tabel 4.29 nilai tabel yang digunakan sebagai nilai kritis pada uji parsial atau uji t sebesar 1.661 yang diperoleh dari tabel t pada $\alpha=0.1$ dan derajat bebas 96 untuk pengujian satu pihak.

a. Kualitas Produk (X1)

Dihipotesiskan bahwa kualitas produk berpengaruh positif tidak signifikan terhadap ketidakpuasan konsumen pada Restoran Sangkuriang Bandung, karena karena dugaan tersebut peneliti menetapkan hipotesis penelitian untuk pengujian satu pihak dengan rumusan hipotesis statistic sebagai berikut :

Ho : $\beta 1 \leq 0$ Kualitas produk tidak berpengaruh positif signifikan terhadap ketidakpuasan konsumen di Restoran Sangkuriang Bandung.

Ha : $\beta 1 \geq 0$ Kualitas produk berpengaruh positif signifikan terhadap ketidakpuasan konsumen di Restoran SangkuriangBandung.

Berdasarkan data dari tabel 4.28 diperoleh $t_{\text {hitung variabel kualitas produk }}$

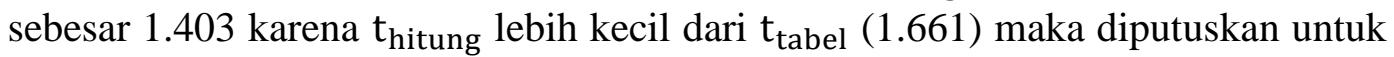
menerima Ho sehingga Ha ditolak artinya dengan tingkat kepercayaan $90 \%$ dapat disimpulkan bahwa kualitas produk tidak berpengaruh signifikan terhadap kepuasan konsumen di Restoran Sangkuriang Bandung.

b. Kualitas Pelayanan $\left(\mathrm{X}_{2}\right)$

Dihipotesiskan bahwa kualitas pelayanan berpengaruh positif signifikan terhadap kepuasan konsumen di Restoran Sangkuriang Bandung, karena digaan tersebut peneliti menetapkan hipotesis penelitian untuk pengujian satu pihak dengan rumusan hipotesis statistik sebagai berikut :

Ho : $\beta 1 \leq 0$ Kualitas pelayanan tidak berpengaruh positif signifikan terhadap ketidakpuasan di Restoran Sangkuriang Bandung.

Ha : $\beta 1 \geq 0$ Kualitas Pelayanan berpengaruh positif signifikan tehadap ketidakpuasan di Restoran Sangkuriang Bandung.

Berdasarkan tabel 4.28 diperoleh $t_{\text {hitung variabel kualitas pelayanan sebesar }}$ 6.863. karena nilai $t_{\text {hitung }}$ lebih besar dari nilai $t_{\text {tabel }}$ (1.661) maka diputuskan untuk menolak Ho sehingga Ha diterima yang artinya dengan tingkat kepercayaan 90\% dapat disimpulkan bahwa kualitas pelayanan tidal berpengaruh signifikan terhadap ketidakpuasan konsumen di Restoran Sangkuriang Bandung.

c. Harga $\left(\mathrm{X}_{3}\right)$

Dihipotesiskan bahwa harga berpengaruh positif signifikan terhadap ketidakpuasan konsumen di Restoran Sangkuriang Bandung, karena dugaan tersebut peneliti menetapkan hipotesis penelitian untuk pengujian satu pihak dengan rumusan hipotesis statistik sebagai berikut : 
Ho : $\beta 1 \leq 0$ Harga tidak berpengaruh positif signifikan terhadap ketidakpuasan di Restoran Sangkuriang Bandung.

Ha : $\beta 1 \geq 0$ Harga berpengaruh positif signifikan terhadap ketidakpuasan di Restoran Sangkurian Bandung.

Berdasarkan tabel 4.28 diperoleh $t_{\text {hitung }}$ variabel harga sebesar

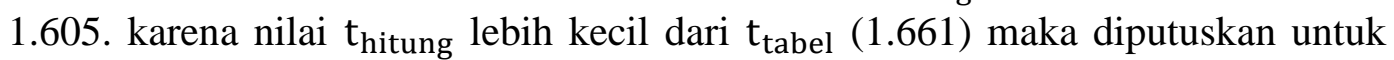
menerima Ho sehingga Ha ditolak, artinya dengan tingkat kepercayaan 90\% dapat disimpulkan bahwa harga tidak berpengaruh signifikan terhadap kepuasan konsumen di restoran Sangkuriang Bandung.

\section{KESIMPULAN}

Menu yang tergolong ke dalam kategori $\operatorname{dog}$ atau menu yang tidak populer dan tidak menguntungkan di Restoran Sangkuriang pada bulan Januari, Februari, Maret, April, Mei dan Juni 2015 adalah telur mata sapi, sambel goang, pencok kacang/leunca, capcai polos, gurame acar kuning, asin gabus, nila asam manis, sup kosong, nasi putih timbel, nila tenyah pedas dan telur rebus.

Berdasarkan hasil penelitian mengenai faktor-faktor yang mempengaruhi ketidakpuasan konsumen terhdap menu kategori dog di Restoran Sangkuriang Bandung, maka pada bagian akhir ini dapt ditarik kesimpulan sebagai berikut :

1. Penilaian variabel kualitas produk yang terdiri dari porsi menu kategori dog yang disajikan cukup baik dan sesuai dengan standar porsi yang telah ditentukan, kelezatan rasa menu kategori dog yang cukup sesuai dengan selera konsumen, penampilan menu kategori dog yang cukup menarik, kebersihan menu kategori dog yang cukup bersih serta ketepatan waktu penyajian yang cukup tepat. Hal ini menunjukan bahwa kualitas produk dari menu kategori dog di Restoran Sangkuriang Bandung cukup baik.

2. Berdasarkan hasil penelitian di Restoran Sangkuriang, penilaian variabel kualitas pelayanan yang terdiri dari ketepatan dan kecepatan waktu penyajian menu kategori dog yang mendapat penilaian cukup sesuai, kemampuan karyawan dalam mengani keluhan dengan penilaian cukup baik, keramahan karyawan yang mendapat penilaian cukup ramah, kepekaan karyawan dalam melayani konsumen dengan penilaian yang cukup baik serta penampilan karyawan yang cukup baik dan rapih. Hal ini menunjukan bahwa kualitas pelayanan di menu kategori $d o g$ di Restoran Sangkuriang cukup baik.

3. Berdasarkan hasil penelitian di Restoran Sangkuriang, penilaian variabel harga yang terdiri dari kesesuaian harga yang ditetapkan dengan menu kategori dog yang mendapat penilaian cukup sesuai serta keterjangkauan harga menu kategori dog yang terjangkau. Hal ini menunjukan bahwa variabel harga ynag ditetapkan oleh Restoran Sangkuriang cukup sesuai dan terjangkau.

4. Berdasarkan variabel yang diuji yaitu variabel kualitas produk, kualitas pelayanan, harga dan kepuasan konsumen dapat diketahui bahwa ketidakpuasan konsumen terhadap menu kategori dog di Restoran Sangkuriang Bandung tidak memiliki porsi yang besar yang berarti konsumen merasa cukup puas dengan menu kategori dog di restoran Sangkuriang Bandung.

5. Berdasarkan hasil pengujian hipotesis uji $\mathrm{t}$ dari tiga variabel yaitu variabel kualitas produk, kualitas pelayanan dan harga menunjukan bahwa variabel 
kualitas produk dan variabel harga memberikan pengaruh terhadap ketidakpuasan konsumen terhadap menu kategori dog di Restoran Sangkuriang Bandung sedangkan variabel kualit pelayanan mendapatkan penialian yang baik sehingga tidak berpengaruh terhadap ketidakpuasan konsumen.

\section{DAFTAR PUSTAKA}

Arief, Abd. Rachman. 2005. Ilmu Perhotelan dan Restoran. Yogyakarta: Graha Ilmu.

Davis, Bernard., dkk. 2008. Food and Beverge Management Fourth Edition. From www.bookzz.org, 23 April 2015.

Darmawan, Deni. 2014. Metode Penelitian Kuantitatif. Bandung: Rosda.

Destriani, Astri Nuraini. 2014. Analisis Faktor-Faktor Yang Berpengaruh Terhadap Ketidakpuasan Konsumen Pada Menu Unpopular dan Unprofitable di Restoran Lokomotif Kuliner Bandung. Skripsi. Jurusan Manajemen Industri Katering. Fakultas Pendidikan Ilmu Pengetahuan Sosial. Universitas Pendidikan Indonesia. Bandung : Tidak Diterbitkan.

Fitrianti, Ratikah. 2014. Analisis Fakto Faktor Ketidakpuasan Konsumen Terhadap Menu Kategori Dog (Unpopuler dan Unprofitable) Di Jadul Village Resort dan Spa. Skripsi. Jurusan Manajemen Industri Katering. Fakultas Pendidikan Ilmu Pengetahuan Sosial. Universitas Pendidikan Indonesia. Bandung : Tidak Diterbitkan.

http://travel.kompas.com/read/2014/04/02/0949478/Menparekraf.Perkembangan.P ariwisata.Indonesia.Paling.Bagus)

Kotler, Phillip \& Keller, Kevin Lane. 2010. Manajemen Pemasaran edisi 1 jilid 1. Jakarta : Erlangga

Kotschevar, Lendal H., dan Diane Withrow. 2008. Management By Menu Fourth Edition. From: www.bookzz.org, 23 April 2015.

Kustiawan. (2013). Analisis Food and Beverages Costing Pada Tomo ramen Restaurant dengan pendekatan Matris. Universitas maritim Ali Haji

Minantyo, Hari. 2011. Dasar- Dasar Pengolahan Makanan. Yogyakarta : Graha Ilmu

Ninemeier, Jack D., David K. Hayes. (2006). Restaurant Operation Management:Principles and Practice. New Jersey: Pearson/Prentice Hall.

Oda.Pengembangan Pusat Kuliner Nusantara Kota Bandung Sebagai Tujuan Wisata.STMP-AKPAR BSI Bandung. http://e-jurnal.kopertis4.or.id

Osndikbud. 2013. Selayang Pandang bandung, Jawa Barat. http://osndikbud.com/tuan-rumah-osn/tuanrumahosn2013/ 4 Desember 2014

PH, Bartono. 2005. Analisis Food Product Studi Food Cost dan Pedoman Training. Yogyakarta: Andi.

Riduwan. 2010. Dasar-Dasar Statistika. Bandung : Alfabeta

Suarsana, Nyoman. 2007. Pengendalian Biaya Departemen F\&B di Perhotelan. Yogyakarta ; Graha Ilmu

Sugiyono. 2012. Metode Penelitian Bisnis. Bandung : Alfabeta.

Sugiyono. 2012. Statistika Untuk Penelitian. Bandung : Alfabeta

Sulastiyono, Agus. 2008. Manajemen Penyelengaraan Hotel. Bandung : Alfabeta. 
Swandana. (2011). Rekayasa Menu. [Online]. Tersedia:http://lihatakuswandana.blogspot.com/2011/08/rekayasa-menu.html.[9 Desember 2014]

Tjiptono, Fandi dan Gregorius Chandra. 2007. Service, Quality \& Satisfaction Edisi tiga. Yogyakarta: Andi Ofset.

Tjiptono, Fandi. 2008. Service Management. Yogyakarta: Andi.

Utama, I.G.Bagus Rai dan Mahadewi, Ni Made Eka. 2012. Metodologi Penelitian Pariwisata dan Perhotelan. Yogyakarta: Andipublisher.

WA, Marsum. 2005. Restoran dan segala permasalahannya. Yogyakarta: Andi.

Widadio, Nicky Aulia. 2014.Menparekraf : Perkembangan Pariwisata Indonesia.Paling Bagus.

http://Travel.compas.com/read/2014/04/02/0949478/Menparekraf.Perkem bangan.Pariwisata.Indonesia.Paling.Bagus. 4 Desember 2014

Wiratha, I.Made. 2006. Metode Penelitian Sosial Ekonomi. Yoghyakarta: Andi.

Wiyasha, I.B.M.2011.F\&B Cost Control.C.V. Yogyakarta: Andi Offset.

Yoeti, Oka A. 2010. Dasar-dasar Pengertian Hospitaliti dan Pariwisata. P.T. Alumni.

Bandung. 